\title{
Lymphoedema-distichiasis syndrome
}

\author{
Nadine Sousa Marques, ${ }^{1}$ Ana Miranda, ${ }^{1}$ Sandra Barros, ${ }^{1}$ Sónia Parreira ${ }^{1,2}$
}

${ }^{1}$ Department of

Ophthalmology, Garcia de Orta Hospital, Lisbon, Portugal

2Department of

Ophthalmology, Garcia de Orta Hospital, Almada, Portugal

\section{Correspondence to}

Nadine Sousa Marques, marques.nadine@gmail.com

Accepted 16 December 2015

\section{DESCRIPTION}

A 29-year-old woman with a history of renal cysts, hypertension and lymphoedema-distichiasis syndrome, was referred to ophthalmology, with bilateral blurred vision, hyperaemia and ocular pain, developed over months.

The patient had no positive family history for lymphoedema-distichiasis or other diseases.

Clinical examination revealed stunted height $(144 \mathrm{~cm})$, neck webbing (figure 1), bilateral and asymmetric lymphoedema (figure 2), bilateral distichiasis (figure 3) and keratitis (figure 4). Other ocular manifestations of lymphoedema-distichiasis,

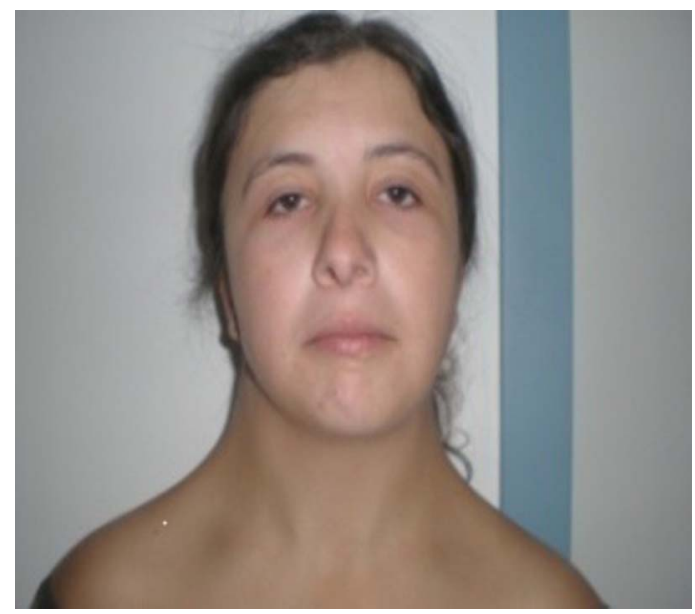

Figure 1 Patient's neck webbing.

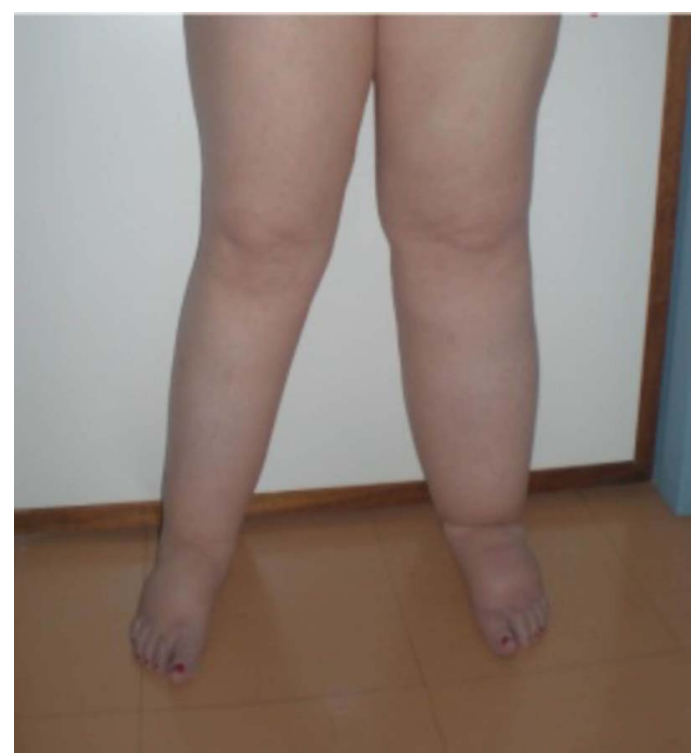

Figure 2 Bilateral and asymmetrical lymphoedema, which the patient presented since puberty, with progressive worsening and episodes of cellulitis.

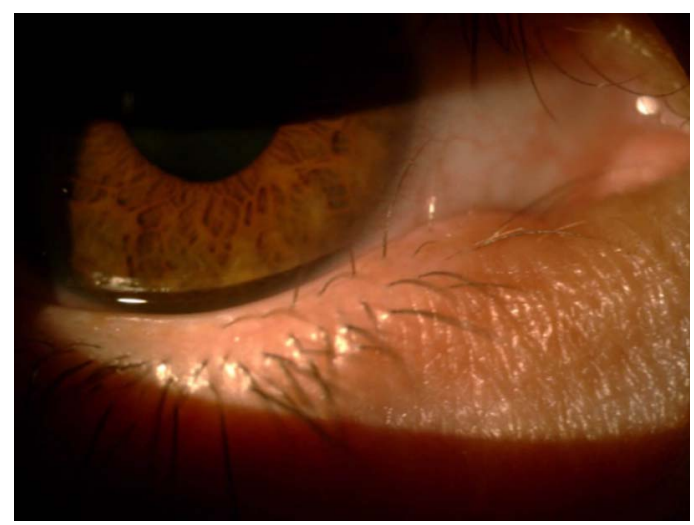

Figure 3 Inferior distichiasis.

such as ptosis and strabismus, were excluded through ophthalmological examination.

Spinal MRI revealed multiple arachnoidal extradural cysts in the thoracolumbar and sacral spine (figure 5, arrows).

The patient's symptoms regressed with bilateral electrolysis of the abnormal follicles after unsuccessful attempts at epilation and follicle removal using an argon laser.

Lymphoedema-distichiasis syndrome is a rare condition, associated with diminished quality of life, being linked with chronic keratitis, conjunctivitis and photophobia in $75 \%$ of cases. Distichiasis, which may be present at birth, is observed in $94 \%$ of affected individuals.

The FOXC 2 gene is the only gene in which mutations are known to cause lymphoedemadistichiasis syndrome. Its protein has a role in a variety of developmental processes, such as formation of veins, lungs, eyes, kidneys, urinary tract, cardiovascular system and lymphatic vessels. Any pathogenic variant of this gene could lead to varicose veins, absence of lymphatic valves, lymphoedema, and cardiovascular and kidney malformations.

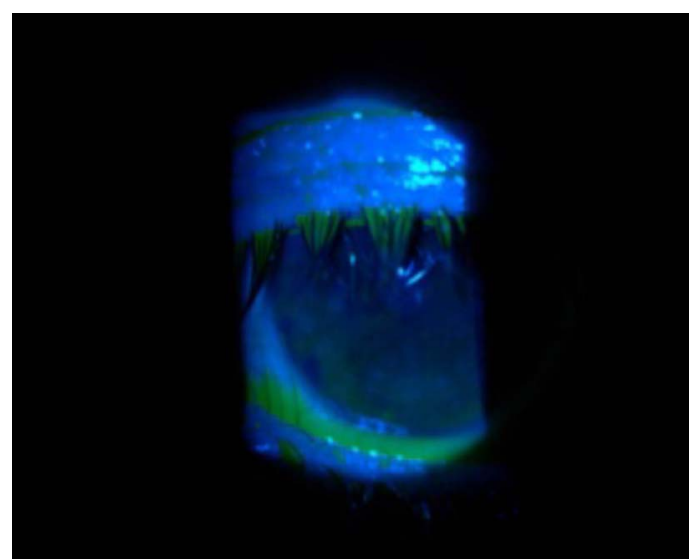

Figure 4 Discrete inferior keratitis. 


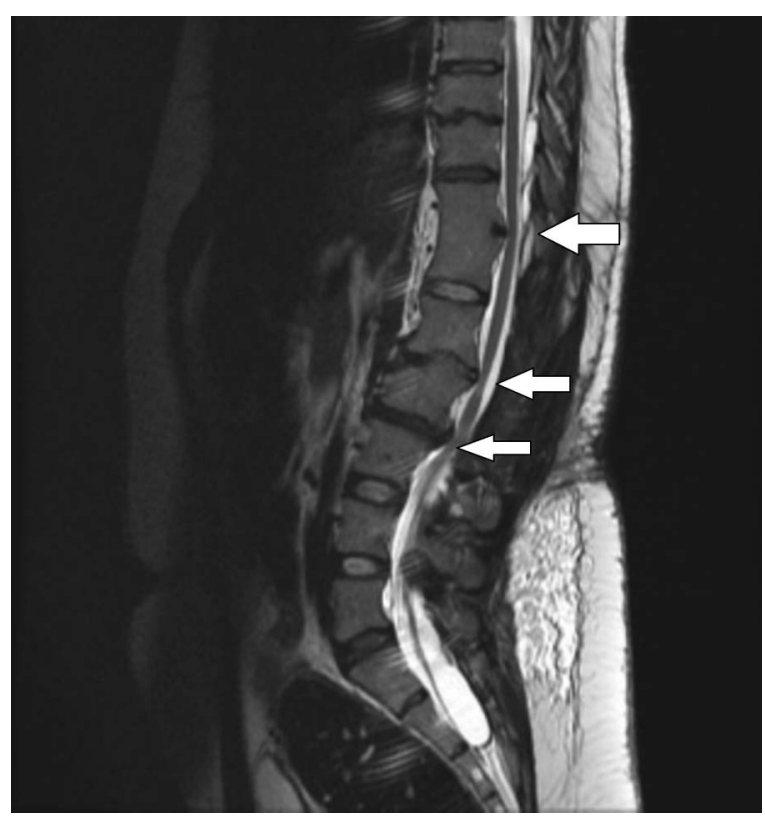

Figure $5 \mathrm{MRI}$, sagittal plane, of the thoracolumbar spine with spinal extradural arachnoid cysts (white arrows).

Our patient did not have a family history for this syndrome. For this reason, lymphoedema-distichiasis syndrome in this case was a probable phenotypic manifestation of a de novo mutation in the FOXC 2 gene.

\section{Learning points}

- The diagnosis of lymphoedema-distichiasis syndrome is made clinically based on the presence of primary lymphoedema and distichiasis. This syndrome can also present with ptosis, strabismus, renal and cardiac abnormalities, spinal extradural cysts, ${ }^{1}$ neck webbing and varicose veins. ${ }^{2}$

- Lymphoedema-distichiasis syndrome is inherited in an autosomal dominant manner. Approximately $75 \%$ of affected individuals have an affected parent; about $25 \%$ have de novo pathogenic variants. ${ }^{3}$

- Conservative management of symptomatic distichiasis is with lubrication or epilation, or more definitive management with cryotherapy, electrolysis or lid splitting. Recurrence is possible even with more definitive treatment.

Competing interests None declared.

Patient consent Obtained.

Provenance and peer review Not commissioned; externally peer reviewed.

\section{REFERENCES}

1 Yabuki S, Kikuchi S, Ikegawa S. Spinal extradural arachnoid cysts associated with distichiasis and lymphedema. Am J Med Genet A 2007;143A:884-7.

2 Brice $\mathrm{G}$, Mansour S, Bell R, et al. Analysis of the phenotypic abnormalities in lymphoedema-distichiasis syndrome in 74 patients with FOXC2 mutations or linkage to 16q24. J Med Genet 2002:39:478-83.

3 Kolin T, Johns KJ, Wadlington WB, et al. Hereditary lymphedema and distichiasis. Arch Ophthalmol 1991;109:980-1.

Copyright 2016 BMJ Publishing Group. All rights reserved. For permission to reuse any of this content visit http://group.bmj.com/group/rights-licensing/permissions.

BMJ Case Report Fellows may re-use this article for personal use and teaching without any further permission.

Become a Fellow of BMJ Case Reports today and you can:

- Submit as many cases as you like

- Enjoy fast sympathetic peer review and rapid publication of accepted articles

- Access all the published articles

- Re-use any of the published material for personal use and teaching without further permission

For information on Institutional Fellowships contact consortiasales@bmjgroup.com

Visit casereports.bmj.com for more articles like this and to become a Fellow 